\title{
Use of multiplex PCR assay for detection of diarrheagenic Escherichia coli in street vended food items
}

\author{
Nishat Sarker ${ }^{1}$, Sharmin Islam ${ }^{1}$, Mehedi Hasan ${ }^{1}$, Farzana Kabir $^{1}$, Md. Aftab Uddin ${ }^{2}$, \\ Rashed Noor ${ }^{2, *}$ \\ ${ }^{1}$ Centre for Communicable Diseases, International Centre for Diarrhoeal Disease Research, Bangladesh (icddr, b), Dhaka, Bangladesh \\ ${ }^{2}$ Department of Microbiology, Stamford University Bangladesh, 51 Siddeswari Road, Dhaka 1217, Bangladesh
}

Email address:

noor.rashed@yahoo.com (R. Noor)

\section{To cite this article:}

Nishat Sarker, Sharmin Islam, Mehedi Hasan, Farzana Kabir, Md. Aftab Uddin, Rashed Noor. Use of Multiplex PCR Assay for Detection of Diarrheagenic Escherichia Coli in Street Vended Food Items. American Journal of Life Sciences. Vol. 1, No. 6, 2013 , pp. $267-272$. doi: 10.11648/j.ajls.20130106.15

\begin{abstract}
Pathogenic forms of Escherichia coli are commonly known to cause a variety of diarrheal diseases in hosts. Present study was designed to identify such pathogenic E. coli isolates from 7 different groups of street vended foods including cream, egg, non fried dry food and fried dry food, salad, cooked and non cooked items. Among 400 samples studied, almost all were found to be contaminated with an array of bacteria ranging between $3.24 \times 10^{2}-6.5 \times 10^{9} \mathrm{cfu} / \mathrm{g}$. Results of multiplex polymerase chain reaction (PCR) assay revealed that out of 130 isolates of E. coli screened from all categories of food items, $52(13 \%)$ were found to be enterotoxigenic E. coli, $32(8 \%)$ were the Shiga toxin producing E. coli isolates, 14 $(3.5 \%)$ were enteropathogenic and $6(1.5 \%)$ were found to be enteroinvasive isolates. Results of plasmid profiling of the isolates was further in agreement to the presence of different pathogenic E. coli strains.
\end{abstract}

Keywords: Street Vended Foods, Microbiological Spoilage, Escherichia coli, Antibiotic Resistance, Multiplex Polymerase Chain Reaction (PCR)

\section{Introduction}

People of Bangladesh and of other countries are gradually getting habituated in consuming foods available around the street side because of their ease of availability, convenience, simplicity of handling, low-cost and some of the appealing factors making street foods popular [1]. However, the microbial hygiene in such practice may underlie within the quality of food items consumed and the frequency of microbial shedding from the food handlers as well their style of handling, preparing and serving food [2-5]. Street vended foods such as poultry, beef, fish, water, juice and rice, which are sold in the street, are frequently identified as vehicles of disease transmission especially in the developing countries with high density of population [6-9]. Therefore, it is necessary to characterize the target microbial pathogen(s) in order to develop a suitable diagnostic test to detect them.

The common food borne enteric bacterial population is known to be largely dominated by the diarrheagenic Escherichia coli (DEC) [10, 11]. Commonly isolated diarrheagenic E. coli are the enteropathogenic (EPEC) strains, with an increased expression of eae gene [12] encoding proteins involved in the formation of attaching and effacing $(\mathrm{A} / \mathrm{E})$ lesions on host intestinal cells. Enterohemorrhagic E. coli (EHEC) or Shiga toxin producing $E$. coli (STEC) is the cause of hemolytic uremic syndrome, with an increased expression of stx 1 and $s t x 2$ genes. The ipaH gene in enteroinvasive E. coli (EIEC) strains is similar to Shigella spp., responsible for inducing dysenteric enteritis in human $[13,14]$.

In general the diagnosis of $E$. coli demands a number of different selective media and biochemical reagents with an increased test frequencies. Also, the traditional techniques don't allow the detection of virulent genes thereby tending the method to be less specific regarding public health measure. Alternatively, a more specific and sensitive method using the multiplex polymerase chain reaction (PCR) system might be used to reduce the number of tests needed for diagnosis of DEC strains in the traditional procedure $[15,16]$. Followed by such rationalization, present study thus employed multiplex PCR assay in addition to the conventional methods to identify pathogenic E. coli strains from different types of common food items. 
collected from street vendor in Dhaka Metropolis.

\section{Materials and Methods}

\subsection{Sample Collection and Processing}

A total of 400 food samples of 7 categories were randomly collected (Table 1) aseptically, kept in the ice box maintaining $4{ }^{\circ} \mathrm{C}$ during transportation, and were analyzed within 2 hours of collection. Ten grams of each sample was transferred to $90 \mathrm{ml}$ of sterile Ringer solution and was homogenized. For microbiological assay, the homogenized suspensions were subject to serial dilutions up to $10^{-6}$.

\subsection{Microbiological Examination of Collected Samples}

One $\mathrm{ml}$ from each diluted tube was transferred into sterile Plate Count Agar (PCA) media through pour plate method for the enumeration of total heterotrophic bacteria. All PCA plates were incubated into $37{ }^{\circ} \mathrm{C}$ for 24 hours. Rose Bengal Chloramphenicol Agar (RBA) media, facilitating the growth of fungi, was inoculated with $0.2 \mathrm{ml}$ of samples from each diluted tubes and spread. Following incubation of 3-5 days at $25{ }^{\circ} \mathrm{C}$, all the plates were examined.

\subsection{Detection and Confirmation of E. coli Isolates}

Detection of $E$. coli was performed by enrichment technique into $E$. coli (EC) broth followed by incubation at $45{ }^{\circ} \mathrm{C}$ and by the most probable number (MPN) method. Twenty five gram $(25 \mathrm{gm})$ samples were transferred to EC broth and incubated for 24 hours at $45{ }^{\circ} \mathrm{C}$. Following enrichment into EC broth, a loopful inoculum was transferred into Methylene Blue (EMB) agar plates, and incubated for $18-24$ hours at $37^{\circ} \mathrm{C}$. Typical colonies with green metallic sheen on EMB Agar media was presumptively considered as E. coli. For MPN method, Lauryl Sulfate Broth (LST broth) \& Brilliant Green 2\% bile broth were used. Media was prepared in McCartney tube with inverted Durham's tube into it and gas production in the tube indicated the positive result. Samples were inoculated into LST broth and incubated for 24 hours at $37{ }^{\circ} \mathrm{C}$. Upon gas formation, a loopful inoculum was transferred to Brilliant Green bile broth and incubated for 24 hours at $37{ }^{\circ} \mathrm{C}$. Numbers of gas forming tubes were then recorded and compared with the standard chart [17]. The morphological and confirmative biochemical tests were further carried out using standard protocol [18].

\subsection{Determination of Antimicrobial Susceptibility by Kirby-Bauer Method}

A uniform lawn of bacterial growth was prepared on Mueller Hinton agar plate. Antibiotic discs were applied aseptically of the surface of the plates at appropriate spatial arrangements. Plates were then incubated at $37{ }^{\circ} \mathrm{C}$ for 24 hours. Commercially available antibiotic discs (Oxoid, Hampshire, UK) were used for the test: ampicillin, (AMP

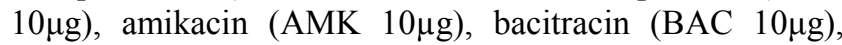

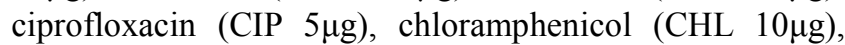

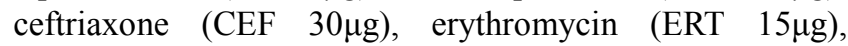

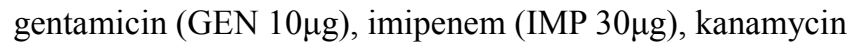

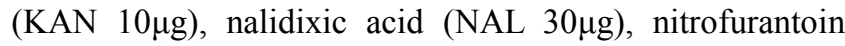
(NTF 10 $\mu \mathrm{g}$ ), penicillin (PEN 10 $\mu \mathrm{g}$ ), piperacillin (PIP 10 $\mu \mathrm{g}$ ),

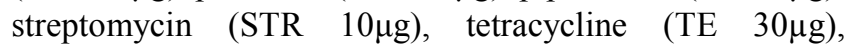
trimethoprim- sulfamethoxazole (TMP-SFM 25 $\mu \mathrm{g}$ ) and vancomycin $(30 \mu \mathrm{g})$. Susceptibility of organism to antibiotic was interpreted by the presence of clear zone around the disc $[16,19,20]$.

Table 1. Food samples with number and category

\begin{tabular}{ccc}
\hline Groups & Food Sample Name & Street food category \\
\hline Group-1 & Meonise, Cream Cake, Butter cake, Cream roll, Pasty Cake & Cream based food \\
Group-2 & Pudding, Cake, Egg chop, & Egg based food \\
Group-3 & Toast, Biscuit, Dry Cake, Dry Pitha, & Non fried dry food \\
Group-4 & Singara, Somucha, Potato chop, Beguni, Piaju & Fried dry food \\
Group-5 & $\begin{array}{r}\text { Normal salad, Mix Vegetable Salad, Chicken salad, Chicken } \\
\text { macaroni salad, special fruit salad }\end{array}$ & Salad \\
Group-6 & Chotpoti, Fuchka, Chola, Belpuri, Noodles & Cooked food \\
Group-7 & Chicken nugget, Meat Ball, Chicken sausage, Chicken Sandwich & Non cooked processed food \\
\hline
\end{tabular}

\subsection{Plasmid Profiling of Selected Isolates}

Plasmid extraction was done according to some modification of alkaline lysis method as described previously [21, 22]. Isolates were grown overnight in LB broth (HiMedia, India) (with $2 \% \mathrm{NaCl}$ ) and cell pellet was collected by centrifugation in $13000 \mathrm{rpm}$ for 5 minutes, which was resuspended in $20 \mu \mathrm{l}$ of TE buffer (50mM Tris, 1 mM EDTA, $\mathrm{pH}$ 8.0). Cells were lysed by adding $100 \mu \mathrm{l}$ of 
lysis buffer (50 mMTris, $3 \% \mathrm{SDS}, \mathrm{pH} 12.6$ ) to each tube, gently mixed and incubated at $56^{\circ} \mathrm{C}$ for 30 minutes followed by the addition of $100 \mu \mathrm{l}$ chilled Phenol: chloroform: iso-amyl alcohol (25:24:1). After shaking the homogenous mixture was centrifuged for $15 \mathrm{~min}$ at $13000 \mathrm{rpm}$. Forty (40) $\mu \mathrm{l}$ from the upper aqueous phase (consisting of plasmid) was removed to a clean Eppendorf tube, and electrophoresed on $0.8 \%$ agarose gel for $1 \mathrm{~h}$ at $90 \mathrm{~V}$ followed by ethidium bromide $(0.5 \mu \mathrm{g} / \mathrm{ml})$ staining. The gel was then visualized on a UV trans-illuminator (Bio-Rad, 170-8195). The size of plasmid was measured by comparing the band with a $1 \mathrm{~kb}$ ladder band and reference strains (Table 2).

\subsection{Identification of E. coli by Multiplex PCR Assay}

Selected isolates were overnight grown in $2 \mathrm{ml}$ Luria-Bertani (LB) broth at $37^{\circ} \mathrm{C}$ with shaking. Thirty-six $\mu l$ of culture was added to $4 \mu \mathrm{l}$ of $10 \times$ Tris-EDTA buffer, and $60 \mu \mathrm{l}$ of $2 \times$ proteinase $\mathrm{K}$ buffer. After incubation at $56^{\circ} \mathrm{C}$ for $90 \mathrm{~min}$ and $10 \mathrm{~min}$ at $95^{\circ} \mathrm{C}$, the sample was centrifuged at $10,000 \mathrm{~g}$ for $1 \mathrm{~min}$, and the supernatant was used as DNA template. The reference strains and primers used in this study are listed in Table 2.

PCR was conducted using standard protocol [14]. The optimized procedure was carried out with a 50 - $\mu$ l mixture containing Tris- $\mathrm{HCl}$ (10 mM, pH 8.3), $\mathrm{KCl}$ (50 mM), $\mathrm{MgCl}_{2}$ (2 mM), gelatin $(100 \mu \mathrm{g} / \mathrm{mL})$, glycerol $(5 \% \mathrm{v} / \mathrm{v})$, dNTP $(200$ $\mu \mathrm{M})$, Taq polymerase $(0.5 \mathrm{U} / 23 \mu \mathrm{L}) ; 0.25 \mu \mathrm{M}$ of each primer and $5 \mu \mathrm{l}$ of the DNA template. The PCR program was $95^{\circ} \mathrm{C}$ for $1 \mathrm{~min}, 52^{\circ} \mathrm{C}$ for $1 \mathrm{~min}$, and $72{ }^{\circ} \mathrm{C}$ for $1 \mathrm{~min}$, for 30 cycles, and $72{ }^{\circ} \mathrm{C}$ for $10 \mathrm{~min}$. PCR products were then electrophoresed on a $2.5 \%$ agarose gel (Takara; Bio-Rad Laboratories), stained with ethidium bromide, and visualized by UV trans-illuminator.

Table 2. Primers used for multiplex PCR assays

\begin{tabular}{|c|c|c|c|}
\hline Strain & Locus & Primer sequence & $\begin{array}{l}\text { Size } \\
\text { (bp) }\end{array}$ \\
\hline ETEC & $l t$ & $\begin{array}{l}\text { F:5'GGC GAC AGA TTA TAC CGT GC3' } \\
\text { R:5'CGG TCT CTA TAT TCC CTG TT3' }\end{array}$ & 440 \\
\hline ETEC & $s t$ & $\begin{array}{l}\text { F:5'ATT TTT CTT TCT GTA TTG TCT T3' } \\
\text { R:5'CAC CCG GTA CAA GCA GGA TT3' }\end{array}$ & 191 \\
\hline EPEC & $b f p \mathrm{~A}$ & $\begin{array}{l}\text { F:5 'AAT GGT GCT TGC GCT TGC TGC3' } \\
\text { R:5' GCC GCT TTA TCC AAC CTG GTA3 }\end{array}$ & 324 \\
\hline EPEC & eaeA & $\begin{array}{l}\mathrm{F}: 5^{\prime} \text { GAC CCG GCA CAA GCA TAA GC3' } \\
\text { R:5'CCA CCT GCA GCA ACA AGA GG3' }\end{array}$ & 384 \\
\hline STEC & stx 1 & $\begin{array}{l}\text { F:5'CTG GAT TTA ATG TCG CAT AGT G3' } \\
\text { R:5'AGA ACG CCC ACT GAG ATC ATC3 }\end{array}$ & 150 \\
\hline STEC & stx 2 & $\begin{array}{l}\text { F:5'GGC ACT GTC TGA AAC TGC TCC3' } \\
\text { R:5'TCG CCA GTT ATC TGA CAT TCT G3 }\end{array}$ & 255 \\
\hline EIEC & ial & $\begin{array}{l}\text { F:5'GGT ATG ATGATGATG AGT CCA } 3 \\
\text { 'R:5' GGA GGC CAA CAA TTA TTT CC } 3 \text { ' }\end{array}$ & 650 \\
\hline
\end{tabular}

\section{Results and Discussion}

\subsection{Prevalence of Microorganisms in the Food Samples}

E. coli strains are the principal pathogens resulting in food borne disease outbreaks [22-26]. In the current study, A huge array of microorganisms was observed (Table 3 ). The lowest bacterial count was found in Group 7 and the highest was in Group 6 (Table 3). The highest fungal load was observed in Group 6, i. e., in the cooked food samples. The huge microbial contamination in the samples revealed that the food items sold in roadside might encounter the environmental factors promoting microbial access.

Table 3. Total viable bacterial and fungal load.

\begin{tabular}{ccc}
\hline Sample groups & $\begin{array}{c}\text { Total bacterial count } \\
(\mathbf{c f u} / \mathbf{g})\end{array}$ & $\begin{array}{c}\text { Total fungal count } \\
(\mathbf{c f u} / \mathbf{g})\end{array}$ \\
\hline Group 1 & $2.6 \times 10^{4}-6.52 \times 10^{7}$ & $2.32 \times 10^{2}-2.3 \times 10^{4}$ \\
Group 2 & $5.72 \times 10^{4}-9.15 \times 10^{7}$ & $2.13 \times 10^{2}-4.9 \times 10^{5}$ \\
Group 3 & $9.6 \times 10^{3}-4.52 \times 10^{8}$ & $1.52 \times 10^{2}-4.32 \times 10^{4}$ \\
Group 4 & $4.62 \times 10^{5}-7.62 \times 10^{8}$ & $2.54 \times 10^{2}-3.21 \times 10^{5}$ \\
Group 5 & $5.72 \times 10^{4}-1.52 \times 10^{8}$ & $2.51 \times 10^{2}-8.15 \times 10^{5}$ \\
Group 6 & $3.94 \times 10^{5}-6.5 \times 10^{9}$ & $2.32 \times 10^{2}-9.6 \times 10^{5}$ \\
Group 7 & $3.24 \times 10^{2}-3.24 \times 10^{6}$ & $5.15 \times 10^{2}-7.73 \times 10^{4}$ \\
\hline
\end{tabular}

\subsection{Prevalence of $E$. coli}

As per our current study, presence of E. coli as well as the presence of coliforms in the food samples studied may indicate fecal contamination which might be due to insufficient cooking, use of raw vegetables, cross contamination between raw and cooked food and contaminated ingredients [24]. The highest number of Escherichia isolates was found in Group 6 referring to the cooked food items. Considering the amount of samples per group the highest prevalence was observed in Group 5 (salad items). The presence of E. coli in salad items is consistent to our previous study [27]. However, the lowest prevalence of $E$. coli was found in Group 7 (non cooked processed foods).

\subsection{Drug-Resistance Traits of the Isolates}

The isolates were found to exhibit $100 \%$ sensitivity against imipenem (IMP), 95\% against amikacin (AMK), 94\% against kanamycin (KAN) and 90\% against nalidixic acid (NAL) (Figure 1). Isolates showed 16\% resistance against trimethoprim-sulfamethoxazole (TMP-SFM), 18\% against chloramphenicol (CHL), 28\% against tetracycline (TE). Since these drugs are known to be highly effective against E. coli [28], our results are assumptive of the probable presence of resistance gene [29]. Due to uncontrolled use of antimicrobial agents, such high incidence of multi-drug resistance may apparently prevail which may ultimately replace the drug sensitive microorganisms from antibiotic saturated environment [30]. 


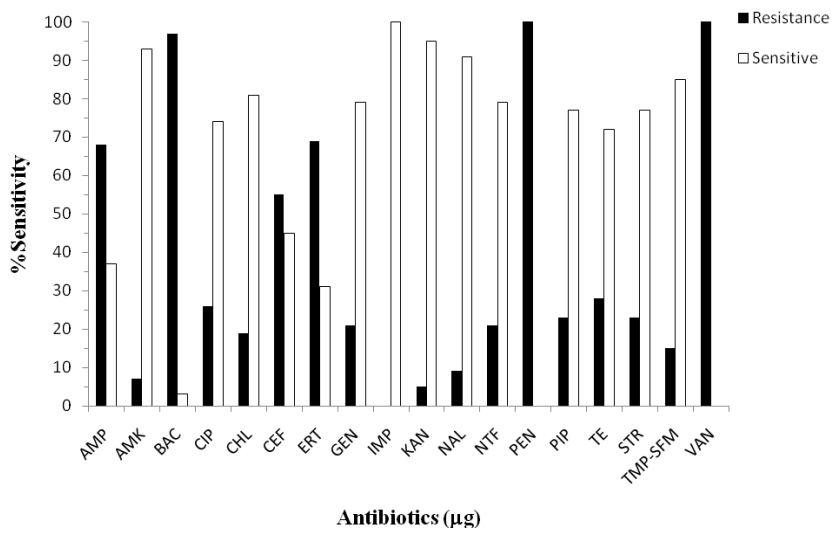

Figure 1. Antibiotic susceptibility pattern of the isolated E. coli $(n=130)$ against different antibiotic which were measured in vitro through Kirby-Bauer method. Commercially available antibiotics used for the assay as mentioned in Materials and Method section.

\subsection{Demonstration Drug-Resistance through Plasmid Profiling}

Plasmid profile analysis has been widely used in epidemiological investigations [11]. In our study, the plasmid profiling of antibiotic resistant E. coli isolates revealed that the isolates consisted of plasmids of various sizes such as $1200 \mathrm{bp}, 1700 \mathrm{bp}, 2500 \mathrm{bp}, 3800 \mathrm{bp}$, 5000bp, $7000 \mathrm{bp}$ and $8000 \mathrm{bp}$ (Figure 2). Several isolates showed very similar plasmid profiles. However, isolates that showed multiple drug resistance were also found to harbor plasmids with sizes ranging from $1 \mathrm{~kb}$ to $8 \mathrm{~kb}$. Although some isolates exhibited different antibiotic resistance patterns, some of their plasmids showed similar pattern of migration; for example, band with the size of $5000 \mathrm{bp}$ was almost common in all lanes (Figure 2).

\subsection{Multiplex PCR Assay for Identification of Specific Group of E. coli}

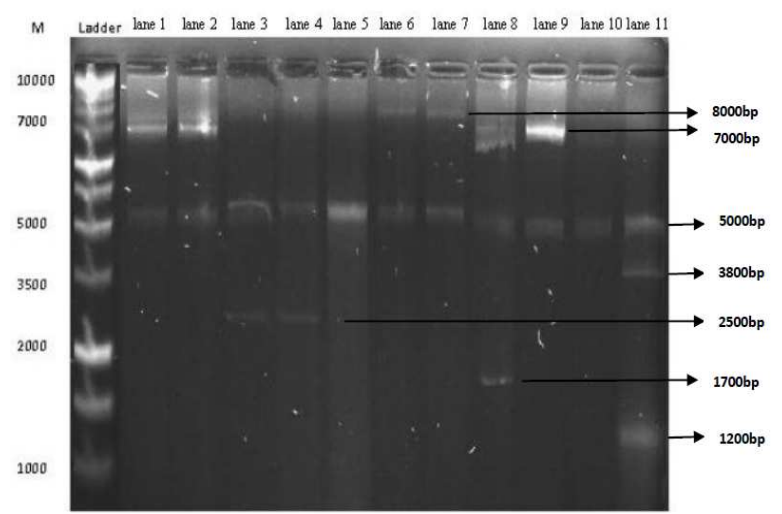

Figure 2. Plasmid profile of E. coli isolates. Lane 1 indicates the Ladder DNA. Lane 2 to lane 10: E. coli isolates isolated from food samples. All of the isolates showed bands at around $5000 \mathrm{bp}$.

In this study for detection of four different categories of E. coli concurrently, a mixture of seven primer pairs were used for multiplex PCR assays which showed 100\% specificity in identifying the reference strains. PCR products of the multiplex PCR assays derived from the pure cultures of reference strains of EPEC, EIEC, STEC, ETEC and clinical isolates. For the final confirmation of $E$. coli presence and their type, Multiplex PCR has been carried out. Form our study; the PCR assays detected 52 (13\%) ETEC isolates, 32 (8\%) STEC isolates, 14 (3.5\%) EPEC isolates and $6(1.5 \%)$ EIEC isolates.

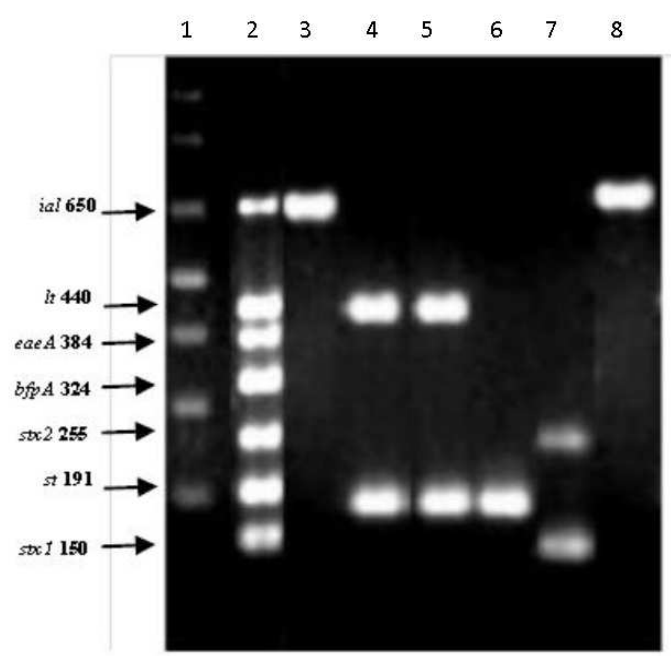

Figure 3. Multiplex PCR of reference strains and food samples. Lane 1: $P C R$ products of each locus in base pairs, obtained from DNA mix of the four reference strains and the primer mix., Lane 2: $1 \mathrm{~kb}$ molecular weight marker in base pairs; Lanes 3-8: PCR products of isolates. In lane 3: ial (650bp) which was indicative of EIEC; lane 4, 5 and 6 was same: $l t$ (440bp) and st (191bp) indicative of ETEC; lane 7 stx1(150bp) and stx2 (255bp) indicates STEC.

As depicted from Figure 3, the highest prevalence was recorded for the ETEC isolates. The virulence gene of EPEC was bfpA (324bp) and eaeA (384bp), ETEC was $l t$ (440bp) and st (191bp), EIEC was ial (650bp), stx1 (150bp) and stx2 (255bp). Several recent studies have reported an increase in prevalence of atypical ETEC strains as has also been found in our study [31]. However, the prevalence of EPEC (3.6\% in the diarrhea group) was lower in our study than in some previous studies [32].

The limitations associated with traditional diagnostic techniques can be overcome by PCR which is a sensitive, specific and rapid method for diagnosis. This study showed that multiplex amplification of nucleic acid can be used as a replacement for conventional method in detection of diarrheagenic E. coli strains. Conventional method requires multiple test and approximately 7 days are required to get confirmatory results whereas multiplex PCR assay requires only 3 days.

\section{Conclusions}

The presence of E. coli in food items as found in our study is assumptive of the probable presence of other pathogenic microorganisms which may generate serious food borne complications. Further research on drinking water associated with the food items studied would expand the total prevalence of the pathogenic E. coli and other 
microorganisms. Another important aspect of our findings lies over the detection of virulent genes which is not only confirmative of the study appropriateness, but also makes a way to endorse the rapid molecular diagnosis over the conventional cultural and biochemical methods. Finally, the results presented here could be sufficient to comprehend the unhygienic state of street foods and hence safety measures are to be initiated in order to control food spoiling microorganisms.

\section{Acknowledgements}

Authors are thankful to Atlas Food R\&D Sector to undertake this study with finance.

\section{References}

[1] Hanashiro, A., Morita, M., Matte, G.R., Matte, M.H., Torres, E.A.F.S., (2005) Microbiological quality of selected street foods from a restricted area of Sao Paulo city, Brazil. Food Control 16, 439-444.

[2] Akobundu, E.N.T., (1996) Packaging of street foods. Paper delivered at Workshop on Street Foods Organized by Nigerian Institute of Food Science and Technology, University of Agriculture, New Delhi.

[3] Lee, W,H., Sakari, T., Lee, M., Hamakawa, M., Lee, S., Lee, I., (1996) An epidemiological study of food poisoning disorders in Korea and Japan. International Journal of Food Microbiology 29 (2-3), 141-148.

[4] Bryan, F.L., Michanie, S.C., Alvare, P.Z., Paniagua, A., (1988) Critical control points of street-vended foods in dominican republic. Journal of Food Protection 51, 373-383.

[5] Muinde, O.K., Kuria, E., (2005) Hygenic and sanitary practices of vendors of street foods in Nairobi, Kenya. African Journal of Food, Agriculture, Nutrition and Development 5, 1-13.

[6] Nicolas, B., Razack, B.A., Yollande, I., Aly, S., Tidiane, O.C.A., (2007) Street-vended foods improvement: Contamination mechanisms and application of food safety objective strategy: Critical review. Pakistan Journal of Nutrition 6, 1-10.

[7] Farzana, K., Akram, M. R., Mahmood, S., (2011) Prevalence and antibiotic susceptibility patterns of some bacterial isolates from a street vended fruit product. African Journal of Microbiology Research 5 (11), 1277-1284.

[8] Noor, R., Uddin, M.A., Hoque, M.A., Munshi, S.K., Acharjee, M., Rahman, M.M., (2013) Microbiological study of vendor and packed fruit juices locally available in Dhaka city, Bangladesh. International Food Research Journal 20 (2), 1011-1015.

[9] Karunasagar, I., Karunasagar, I., Kumar, S.H., (2002) Molecular methods for rapid and specific detection of pathogens in seafood. Aquaculture Asia 3, 34-37.

[10] Galane, P.M., Le Roux, M., (2001) Molecular epidemiology of Escherichia coli isolated from young South African children with diarrhoeal diseases. Journal of Health Population and Nutrition 19 (1), 31-38.
[11] Kalantar, E., Soheili, F., Salimi, H., Dallal, S.M.M., (2011) Frequency, antimicrobial susceptibility and plasmid profiles of Escherichia coli pathotypes obtained from children with acute diarrhea. Jundishapur Journal of Microbiology 4 (1), 23-28.

[12] Rappelli, P., Maddau, G., Mannu, F., Colombo, M.M., Fiori, P.L., Cappuccinelli, P., (2001) Development of a set of multiplex PCR assays for the Simultaneous identification of enterotoxigenic, enteropathogenic, enterohemorrhagic and enteroinvasive Escherichia coli. The New Microbiologica 24 (1), 77-83.

[13] Vidal, M., Kuger, E., K., Duran, C, Lagos, R., (2005) Single multiplex PCR assay to identify simultaneously the six categories of diarrheagenic Escherichia coli associated with enteric infections. Journal of Clinical Microbiology 43, $5362-5365$

[14] Aranda, K.R.S., Fabbricotti, S.H., Fagundes-Neto, U., Scaletsky, I.C.A., (2007) Single multiplex assay to identify simultaneously enteropathogenic, enteroaggregative, enterotoxigenic, enteroinvasive and Shiga toxin producing Escherichia coli strains in Brazilian children. FEMS Microbiology Letters 267, 145-150.

[15] Nataro, J.P., Kaper, J.B.,(1998) Diarrheagenic Escherichia coli. Clinical Microbiology Review 11, 142-201.

[16] Munshi, S.K., Rahman, M.M., Noor, R., (2012) Detection of virulence potential of diarrheagenic Escherichia coli isolated from surface water of rivers surrounding Dhaka City. Journal of Bangladesh Academy of Sciences 36 (1): 109-122.

[17] APHA (American Public Health Association), (1998) Standard Methods for the Examination of Water and Wastewater. 20th ed. American Public Health Association, Washington, D.C.

[18] Feng, P., Weagant, S., Grant, M., (2002) Enumeration of Escherichia coli and the coliform bacteria. In: Bacteriological Analytical Manual, 8th ed. FAD/Center for Food Safety \& Applied Nutrition.

[19] Bauer, A.W., Kirby, W.M.M., Sherris, J.C., Tierch, M., (1966) Antibiotic susceptibility testing by a standardized single disc method. American Journal of Clinical Pathology 45 (4), 493-496.

[20] Ferraro, M.J., Craig, W.A., Dudley, M. N., (2001) Performance standards for antimicrobial susceptibility testing. 11th ed. NCCLS, Pennsylvania, USA.

[21] Kado, C.I., Liu, S.T., (1981) Rapid procedure for detection and isolation of large and small plasmids. Journal of Bacteriology 145, 1365-1373.

[22] Tessi, M.A., Aringoli, E.E., Pirovani, M.E., Vincenzini, A.Z., Sabbag, N.G., Costa, S.C., (2002) Microbiological quality and safety of ready-to-eat cooked foods from a centralized school kitchen in Argentina. Journal of Food Protection 65 (4), 636-642.

[23] Dawson, R., Liamrandsi, S., Boccas, F.,(1996) Bangkok's street food project. Food, Nutrition and Agriculture / Alimentation Nutrition and Agriculture, FAO Publication $17 / 18$.

[24] Eley, A.R., (1996) Toxic bacterial food poisoning. In: Eley, A.R., (Ed.), Microbial Food Poisoning, 2nd ed. Chapman and Hall, London, pp. 47. 
[25] Arifeen, S.E., Akhter, T., Chowdhury, H.R., Rahman, K.M., Chowdhury, E.K., Alam, N., Hoque, D.M.E., Baqui, A.H., (2005) Causes of death in children under five years of age. Availableat:

http://www.measuredhs.com/pubs/pdf/FR165/09Chapter09. pdf (Accessed 13 August 2013).

[26] Qadri, F., Svennerholm, A.M., Faruque, A.S., Sack, R.B., (2005) Enterotoxigenic Escherichia coli in developing countries: epidemiology, microbiology, clinical features, treatment and prevention. Clinical Microbiology Review 18, $465-483$.

[27] Rahman, F., Noor, R., (2012) Prevalence of Pathogenic bacteria in common salad vegetables of Dhaka metropolis. Bangladesh Journal of Botany. 41 (2), 159-162.

[28] Mazumdar, K., Dutta, N.K., Dastidar, S.G., Motohashi, N., Shirataki, Y., (2006) Diclofenac in the management of E. coli urinary tract infections. In Vivo 20(5), 613-9.
[29] Dutta, S., Hassan, M.R., Rahman, F., Jilani, M.S.A., Noor, R., (2013) Study of antimicrobial susceptibility of clinically significant microorganisms isolated from selected areas of Dhaka, Bangladesh. Bangladesh Journal of Medical Science 12 (1), 34-42.

[30] Bennett, P.M., (2008) Plasmid encoded antibiotic resistance: Acquisition and transfer of antibiotic resistance genes in bacteria. Brazilian Journal of Pharmacology 153 (1), 347-357.

[31] Franzolin, M.R., Alves, R.C., Keller, R., Gomes, T.A., Beutin, L., Barreto, M.L., (2005) Prevalence of diarrheagenic Escherichia coli in children with diarrhea in Salvador, Bahia, Brazil. Memórias do Instituto Oswaldo Cruz 100, 359-363.

[32] Kaper, J.B., Nataro, J.P., Mobley, H.L., (2004) Pathogenic Escherichia coli. Nature Reviews Microbiology 2, 123-40. 